\title{
Integrated Risk Assessment of Ship Engine Room Fire Based on Fuzzy Vector Similarity
}

\author{
Yu LIU \\ Department of Electromechanical Management \\ China Maritime Police Academy \\ Ningbo, China \\ e-mail: xiaosmu@163.com
}

\author{
Yufeng YANG \\ Department of Ship Commanding \\ China Maritime Police Academy \\ Ningbo, China \\ e-mail: yyf41212@sohu.com
}

\begin{abstract}
Ship engine room fire is more common and more dangerous kind of accident due to fire, explosion caused shipwreck proportion rising year by year. First of all, to determine the evaluation index system, and then carry out random checks on the targets, calculation of the vector correlation of the indicators and targets integrated vector. The vessels engine room fire risk assessment model has been done by fuzzy comprehensive evaluation results.
\end{abstract}

Keywords- cabin fire; index weights; vector similarity; fuzzy comprehensive risk assessment

\section{INTRODUCTION}

Ship engine room fire is more common and more dangerous kind of accident shipwreck. From the 1980s, shipwreck proportion caused by explosion increased year by year due to fire, the average annual loss of tonnage doubled over the 1960s, more than 600,000 gross tons. Ship fire threatens not only the ship itself, the security personnel on board, cargo, etc.but can lead to serious personal injury and substantial property damage, even incalculable environmental damage. Fire military vessels may also result in more serious consequences disastrous.

Its characteristics are a fire caused by electrical equipment. Electrical short circuit inside the cabin overheated, over-current electrical equipment fire caused by fever. High temperature equipment overheating, the fuel poorly ventilated furnace boiler ignition, combustion and explosions of fire. Fire caused by cabin staff negligence. Fire caused by other reasons, such as staff smoking prohibited in the cabin fire.

\section{CABIN FIRE RESEARCH SITUATION}

The complex structure of the ship itself, cabin-intensive, narrow passageways, especially the cabin fire detection even more difficult and dangerous,it is very difficult to ascertain the type and source of fire. The literature [1-3] presented a ship's tactical fire fighting techniques. The literature [4] used tree analysis method to analyze the cabin fire accidents caused by human error and hardware failure triggered by events that led to the top human factors qualitative and quantitative analysis of the occurrence of an event, made a method to reduce the risk of fire occurrence probabilities. [5] studied a fire model fires occur under certain conditions, mechanisms and laws of development and prevention.

\section{Evaluation Method}

\section{A. Establish Factors Set}

Factors set, $X=\left\{x_{1}, x_{2}, \cdots, x_{m}\right\}$, refers to a variety of factors influence the decision-making system evaluation. $x_{i}(i=1,2, \cdots, m)$ were the representatives of the various elements influencing factors. The main factor in ship engine room fire safety system are: ${ }_{1} X=$ \{cabin equipment $\},{ }_{2} X=$ \{human factors $\},{ }_{3} X=$ \{safety management $\}$. They have different degrees of ambiguity, it is a fuzzy set.

\section{B. Fire Assessment Weight}

The weight to determine has more traditional methods, such as expert survey, the weighted statistical method, frequency statistics, AHP, etc[6-8]. In order to reduce the interference of subjective factors, the similarity of vector is used to determine the weight of the evaluation indicators. Vector is constructed by the norm similarity and the direction of similarity. First make sure that the standard system of a state evaluation of various conditions ideal indicators of value, and then compare single factor indicators algorithm. The system of indicators is non-dimensional and normalized and the weight vector is treated.

That $U$ is designed with $U=\left(x_{1}, x_{2}, \cdots, x_{n}\right)$ is an unknown vector, That $V$ is designed with $V=\left(y_{1}, y_{2}, \cdots, y_{n}\right)$ is a known standard vector. $\|U\|$ and $\|V\|$ are norm distance of the vector $U$ and $V$ respectively. $\theta$ is the angle between the vector $U$ and $V$, so the similarity norm of the vector $U$ and $V$ is as follows.

$$
\begin{array}{r}
\xi=\|V\| /\|U\| \text {, if }\|U\| \leq\|V\| \leq 2\|U\|, \\
\xi=1-\|U\|-\|V\| /\|\|_{U \|} \text {,if }\|V\| \geq\|U\|, \xi=0
\end{array}
$$


It is seen in (1) that $\xi$ is the similarity norm of the vector $U$ and $V$. The direction similarity is calculated by the cosine of the angle between the vector $U$ and $V$.

$$
\begin{gathered}
\theta=\arccos \frac{(x, y)}{\|x\| \cdot\|y\|}=\arccos \frac{\sum_{i=1}^{n} x_{i} \cdot y_{i}}{\left(\sum_{i=1}^{n} x_{i}^{2} \cdot \sum_{i=1}^{n} y_{i}^{2}\right)^{1 / 2}}, \\
\eta=1-\frac{\theta}{90^{0}}
\end{gathered}
$$

Where, $\eta$ is the direction similarity between the vector

$U$ and $V$ in (2).

$$
\gamma=\xi \cdot \eta
$$

Where, $\gamma$ is the vector similarity between the vector $U$ and $V$ in formula (3).

Weight indicators steps are as follows.

Firstly, the comprehensive index vector of the systems is established. A system of indicators has a total of $n$ personality indicators, according to a state of ideal circumstances all the known data, establishing indicators system composite indicator vector $I=\left[I_{1}, I_{2}, \cdots, I_{n}\right]$.

Secondly, the target sample comes from system indicators. In order to sample as much as possible to reflect the system, sample capacity to appropriate the more in the case should be allowed. Are taken from various performance indicators in the state system under the group $i$ values (under normal circumstances required $i \geq 6$ ).

Thirdly, each feature vector of the target sample is Calculated. Indicators for the $j$ sample of the feature vector, $X_{j}=\left[x_{1}, x_{2}, \wedge, x_{i}\right]$, Among them, $x_{q}(q=1,2, \wedge, i)$ is the $i$ target group for the system of random sampling data value.

Finally, composite indicator vector of the system and features vector of indicators process non-dimensional. To make the indicator data between the comparability of data for the indicators are as follows transform, to have a unified metrics. A very small indicators $X$ of the non-dimensional approach is to deal with,

$$
x^{\prime}=\frac{p_{2}-x}{p_{2}-p_{1}}
$$

Among them, $p_{2}$ and $p_{1}$ were indicators of $X$ a permit, the maximum and minimum level. A very large indicators of the non-dimensional approach is to deal with

$$
x^{\prime}=\frac{x-p_{1}}{p_{2}-p_{1}}
$$

Therefore, the evaluation index of the treatment by (4) and (5) can be converted into non-dimensional indicators of the maximum. The dimensionless indicators is the evaluation index weights.

\section{Establish the Evaluation Set}

Evaluation of the overall set is a collection of various judges who judge the results might be made the object of evaluation composed. The results of the evaluation of possible cabin fire safety system can be written as follows.

$\mathrm{V}=$ \{very safe (V1), security (V2), safer (V3), general (V4), insecurity (V5)

$\mathrm{V}$ is the set of fuzzy evaluation set fire system cabin comprehensive evaluation.

\section{Fuzzy Comprehensive Evaluation}

Fuzzy evaluation matrix $B_{i}$ established by each index $X_{i}$ pairs of the main criteria layer.

Through the bottom layer of the indicators made the evaluation of the classification factor index. If a separate indicator $X_{i} \quad(i=1,2, \Lambda, n)$ under consideration $X_{i j}$, judge the extent of the first $t$ comments $y_{i j t}$ that are affiliated with $y_{t}$, you can get $X_{i}$ fuzzy evaluation matrix $S_{i}$.

$$
S_{i}=\left[\begin{array}{cccc}
r_{i 11} & r_{i 12} & \cdots & r_{i 1 n} \\
r_{i 21} & r_{i 22} & \cdots & r_{i 2 n} \\
\cdots & \cdots & \cdots & \cdots \\
r_{i m 1} & r_{i m 2} & \cdots & r_{i m n}
\end{array}\right]
$$

Where $i$ is the number of indicators for each classification factor, the $X_{i} \quad(i=1,2, \Lambda, n)$ is evaluation of criteria related to the number of layers in the index, $n$ is the number of reviews focus comment., $m$ is number of reviews focus comment 。

According to the fuzzy transform, a collection of fuzzy comprehensive evaluation of each indicator to obtain the

\begin{tabular}{|c|c|c|c|c|}
\hline $\begin{array}{c}\text { Indicato } \\
\text { rs }\end{array}$ & $\begin{array}{l}\text { Secondary } \\
\text { indicators }\end{array}$ & Three indicators & $\begin{array}{l}\text { Secondar } \\
\text { y index } \\
\text { weights }\end{array}$ & $\begin{array}{c}\text { Three } \\
\text { indicato } \\
\text { rs } \\
\text { weights } \\
\end{array}$ \\
\hline \multirow{4}{*}{$\begin{array}{c}\text { Cabin } \\
\text { equipmen } \\
t\end{array}$} & \multirow{2}{*}{$\begin{array}{l}\text { Prone to } \\
\text { fire } \\
\text { equipment } \\
\text { X1 } \\
\end{array}$} & Oil pipeline X11 & \multirow[b]{2}{*}{0.14} & 0.09 \\
\hline & & $\begin{array}{c}\text { Electrical } \\
\text { equipment X12 }\end{array}$ & & 0.05 \\
\hline & \multirow{2}{*}{$\begin{array}{c}\text { Fire } \\
\text { fighting } \\
\text { equipment } \\
\text { X2 }\end{array}$} & $\begin{array}{c}\text { Automatic fire } \\
\text { alarm system X21 }\end{array}$ & \multirow{2}{*}{0.18} & 0.07 \\
\hline & & $\begin{array}{c}\text { Flame facilities } \\
\text { X22 }\end{array}$ & & 0.11 \\
\hline \multirow[b]{2}{*}{$\begin{array}{l}\text { Human } \\
\text { factors }\end{array}$} & \multirow[b]{2}{*}{$\begin{array}{c}\text { Cabin staff } \\
\text { X3 }\end{array}$} & $\begin{array}{c}\text { Fire training times } \\
\text { annually X31 }\end{array}$ & \multirow[b]{2}{*}{0.2} & 0.06 \\
\hline & & $\begin{array}{l}\text { Persons density } \\
\text { per square meter } \\
\text { X32 }\end{array}$ & & 0.04 \\
\hline
\end{tabular}
main criterion layer by $B_{i}=W_{i} * S_{i}$.

\section{EXAMPLES}

From (1) (2) (3) (4) (5) to give the weight of the evaluation index as shown in Table 1.

TABLE I. EACH INDEX VALUE 


\begin{tabular}{|c|c|c|c|c|}
\hline & & $\begin{array}{c}\text { Fire Awareness } \\
\text { X33 }\end{array}$ & & 0.06 \\
\hline & & $\begin{array}{c}\text { Self-help } \\
\text { capabilities X34 }\end{array}$ & & 0.04 \\
\hline & \multirow{2}{*}{$\begin{array}{c}\text { Other staff } \\
\text { X4 }\end{array}$} & $\begin{array}{c}\text { Fire awareness } \\
\text { X41 }\end{array}$ & \multirow{2}{*}{0.18} & 0.1 \\
\hline & & $\begin{array}{c}\text { Self-help } \\
\text { capabilities X42 }\end{array}$ & & 0.08 \\
\hline \multirow{4}{*}{$\begin{array}{c}\text { Security } \\
\text { managem } \\
\text { ent }\end{array}$} & \multirow{2}{*}{$\begin{array}{l}\text { Security } \\
\text { managemen } \\
\text { t level X5 }\end{array}$} & $\begin{array}{l}\text { Organizational } \\
\text { skills X51 }\end{array}$ & \multirow{2}{*}{0.17} & 0.07 \\
\hline & & $\begin{array}{c}\text { Fire knowledge } \\
\text { and skills X51 }\end{array}$ & & 0.1 \\
\hline & \multirow{2}{*}{$\begin{array}{l}\text { Safety } \\
\text { system } \\
\text { implementa } \\
\text { tion X6 }\end{array}$} & $\begin{array}{c}\text { The annual } \\
\text { number of fire } \\
\text { safety } \\
\text { educationX61 }\end{array}$ & \multirow[t]{2}{*}{0.13} & 0.07 \\
\hline & & $\begin{array}{c}\text { Regular } \\
\text { inspection X62 }\end{array}$ & & 0.06 \\
\hline
\end{tabular}

In order to evaluate the objectivity, we selected six experts for each evaluation scoring. Membership matrix corresponding, [1,0.9,0.8,0.7,0.6], calculated according to the standard features of each indicator, the process of obtaining an example is $X_{3}$ here.

Eigenvectors $X_{3}$ of four evaluation are as follow.

$\left[\begin{array}{cccccc}4 & 4 & 4 & 4 & 4 & 4 \\ 0.12 & 0.12 & 0.12 & 0.12 & 0.12 & 0.12 \\ 0.92 & 0.96 & 0.85 & 0.89 & 0.94 & 0.92 \\ 0.93 & 0.88 & 0.95 & 0.92 & 0.93 & 0.97\end{array}\right]$

After obtaining the corresponding membership, combined with its weight vector $w_{3}$ $\left[\begin{array}{llll}0.06 & 0.04 & 0.06 & 0.04\end{array}\right]$, Main criterion level indicators $X_{3}$ obtained by $B_{i}=W_{i} * S_{i}$ the fuzzy comprehensive evaluation matrix $\left[\begin{array}{llllll}0.3372 & 0.3376 & 0.3338 & 0.335 & 0.3384 & 0.3338\end{array}\right]$ - Similarly, other indicators can be obtained evaluation matrix, and finally get the overall evaluation matrix cabin fire risk assessment, after normalization $S=\left[\begin{array}{llllll}0.896 & 0.824 & 0.901 & 0.836 & 0.912 & 0.825\end{array}\right]$, The average $\bar{S}=0.866$, Ranged between security and safer, so the cabin fire risk is security.

\section{ConClusion}

In order to embody the importance of each evaluation index in the system, the various indicators must be given different weight coefficients. Though there has a lot of weight algorithm, this paper uses vector similarity to determine the weights of evaluation indexes algorithm. The vessels engine room fire risk assessment model has been done by fuzzy comprehensive evaluation results. The rusult of the cabin fire risk is security.

\section{ACKNOWLEDGMENT}

In this paper, the research was sponsored by the Zhejiang Provence Higher Education Classroom Teaching Reform Project (Project No. kg2013494).

\section{REFERENCES}

[1] Guo Xiangcheng. Discussion ship fire detection problem [J]. Maritime Technology News,1997, (9) :9-10.

[2] Shao Jianzhang. Ship fire fighting and rescue [J]. Fire Technique and Products Information, 2002, (8) :44-48.

[3] Jin Liangan,Xu Yuming,Zhang Minhu. Ship fire rescue problems and countermeasures[J]. Seamanship,2002, (2) :73-75.

[4] Zhang Chunlai, Wu Zhaolin.Anthropogenic factors study of cabin fire accidents [J]. Dalian Maritime University, 1999,25 (2) :45-48.

[5] Dong Hua, Fan Weicheng. Ship fire status and development trend in China [J]. Fire Science,1994,3 (2) :44-46.

[6] M. Yao, S. Zhang. Fuzzy consistent matrix is in the application of science [J]. Information systems engineering, 1997,15 (2): 54.

[7] J.J.Zhang. FAHP [M]. Fuzzy systems and mathematics, 2000,14 (2): 80.

[8] Y.M. Qiu, G. Yang. ships'equipment programme and decisionmaking is in the application of Fuzzy AHP [J]. Shipbuilding technology, 2007,2:16. 